\title{
Influence of Some Environmental Parameters on Some Frog Populations and their Parasitc Fauna
}

\section{Wahab A Rahman* and Zatil Shakinah}

School of Food Science and Technology, University Terengganu Malaysia, 21030 Kuala Terengganu, Malaysia

\begin{abstract}
Wild animals, including frogs are usually infected with several species of parasites. Frogs are important for a variety of reasons. Firstly, they control populations of insects and secondly they can act as indicator species to the environment. Studies have shown that frogs can harbor many species of parasites. Worldwide, there were numerous researches carried out on frog parasites but few had been reported from Malaysia. From this study, 300 frogs from 14 species were collected from eight study sites: Duttaphrynus melanostictus, Phrynoidis aspera, Hylarana erythraea, H. labialis, H. nigrovittata, Polypedates leucomystax, Fejervarya cancrivora, F. limnocharis, Limnonectes blythii, L. paramacrodon, L. ibanorum, L. ingeri, Microhylabutleri, and Kaloulapulchra. Eleven (11) helminthic parasites (Heterakis spp., H. vesicularis, Trichostrongylus spp., Pharyngodon spp., Ascaris spp., Oswaldocruzia spp., Rhabdias spp.,Glypthelmins staffordi, Diplodiscusm sacculosus, Manodistomum spp., and Macracanthorynchus spp.), eight blood parasites (a rickettsia, Hepatozoon spp.,Haemogregarina spp., Lankesterella spp., Trypanosoma loricatum, T. rotatorium, T. chattoni, and microfilaria) and one protozoa (Nyctotherus spp.) were recorded from frogs. There were correlations between the presence of helminthic parasites and distribution of rainfall, as well as between blood parasites and Biochemical Oxygen Demand (BOD) of water.
\end{abstract}

Keywords: Frogs; Peninsular malaysia; Parasites; Correlations; Environmental parameters; pH; Rainfall; Biological oxygen demand

\section{Introduction}

Taxonomists have described more than 5,000 species of frogs [1]. Disease has been a factor in the decline of amphibian populations worldwide, although other factors including habitat loss and fragmentation, chemical pollution, climate changes, introduction of exotic species, increased ultraviolet radiation, and natural pollution have also been responsible for the decline [2]. Malaysia is a country with an equatorial climate with high annual humidity ranging from $60 \%$ to $90 \%$ and rainfalls of 2000 to $3000 \mathrm{~mm}$, resulting with a rich diverse biodiversity of wildlife [3]. Malaysia harbors about 165 species from six families of anurans of which more than 150 species are found in Borneo [4], 107 species in Peninsular Malaysia, including 26 species in Penang Island [5].

In Malaysia there had been some reports of helminthic parasites recovered from frogs. Some nematodes had been described from the intestines of frogs [6,7]. Other investigators had described several species of trematodes [8] and one species of cestode [9], also from the intestine of several species of frogs. In Malaysia, reports of blood parasites from frogs are scanty. Yong and Richards [10] reported a new trypanosome, Trypanosoma hosei, from a forest frog, $R$. hosei. Rahman reported the presence of micro filarial worms, and Trypanosoma spp. from the frog hosts of B. melanostictus. At the present time, the emergence and re-emergence of various parasitic organisms and pathogens are caused as a consequence of environmental changes in the environment. Therefore, the effects are determined by relationship between ecology, hosts and other organisms [11]. As reported by Ibrahim et al. [9], environmental factors can contribute to amphibians' parasitism. It is because the animals are exposed to the surrounding harboring this parasite. Population of amphibians worldwide are declining in the recent surveys, and generally it is because of environment changes $[2,9,12]$. The significant decline in amphibian populations has been observed all over the world [12]. Somehow, there is a familiar occurrence where the trends of losses appear to be surpassing the usual population changeability $[10,12]$. Several causes of this problem have been recognized and the environment is the main factor contributing to decline in number of amphibians, for example, ultraviolet (UV) radiation, climate changes [13], pathogens [14], introduction of exotic species [2], pollution, and also pesticides [15].

Environmental changes would probably create an increase in vulnerability of the host in the parasites instead of direct lethal effect to amphibian populations. Previous studies specified that several kinds of stresses comprising the UV radiation were able to cause immunosuppression in mammals. A similar study was conducted on amphibians and the result showed that the ultraviolet radiation is not interrelated with immunosuppression in amphibians. But, high $\mathrm{pH}$ and coldness [16] were verified to initiate alterations in the immune system of frogs. Development of parasites is influenced by environmental factors. In association with this, temperature causes modified development of the parasites in host [17]. Besides, environmental stress has an effect on parasites as well. Primarily, rate of parasitism might increase by the cause of pollution either expanding the host vulnerability or increasing the profusion of intermediate hosts and vectors [18].

\section{Materials and Methods}

\section{Study sites}

Penang Island, Peninsular Malaysia is located near the northwestern coast of Peninsular Malaysia ( $\left.5^{\circ} 24.0^{\prime} \mathrm{N}, 10014.0^{\prime} \mathrm{E}\right)$. Samplings were

*Corresponding author: Wahab A Rahman, School of Food Science and Technology, University Terengganu Malaysia, 21030 Kuala Terengganu, Malaysia, Tel: 09-6684995; E-mail: arawahab@umt.edu.my

Received October 10, 2014; Accepted April 28, 2015; Published April 30, 2015

Citation: Rahman WA, Shakinah Z (2015) Influence of Some Environmental Parameters on Some Frog Populations and their Parasitc Fauna. J Veterinar Sci Technol 6: 227. doi:10.4172/2157-7579.1000227

Copyright: (c) 2015 Rahman WA, et al. This is an open-access article distributed under the terms of the Creative Commons Attribution License, which permits unrestricted use, distribution, and reproduction in any medium, provided the original author and source are credited. 
Citation: Rahman WA, Shakinah Z (2015) Influence of Some Environmental Parameters on Some Frog Populations and their Parasitc Fauna. J Veterinar Sci Technol 6: 227. doi:10.4172/2157-7579.1000227

Page 2 of 5

carried out during May 2010 to May 2011 from eight (8) areas, randomly selected from various parts of the island.

\section{Sample collections}

Collection of frogs was carried out at night between 2000-2300 h using torch lights and head lamps. Besides using butterfly nets, frogs were also caught by hand, especially for those frogs found inside rocks cervices. Captured frogs were kept alive in aquarium boxes and transported back to the laboratory. In the laboratory, the frogs were placed in the sink with running tap water to avoid dehydration of the frog's skin. Species of frogs were identified according to the descriptions of Inger and Stuebing [4]. Subsequently, frogs were killed by using low doses of chloroform. Frogs were then weighed using a top pan digital electronic balance (SHIMADZU Brand Japan).

\section{Parasite recovery}

Each frog was examined for external abnormalities before the animal was euthanized. The stomach, intestines, rectum, heart and liver were recovered and examined for end parasites. Blood samples were drawn from the heart. The frogs were laid on the dissecting tray with belly facing upwards and their legs were pinned with pins. The first incision was done through the top layer of their skin by using a blade scalpel without damaging the organ. The incision was made vertically down the belly. Next, the incision was done laterally across the hind legs and across the throat as well. Then the two lateral incisions were connected together with a vertical incision down the belly. The flaps were opened and pinned down. Subsequently, the same incision was done on the last layer of frogs' skin by twisting the scissor to avoid cutting organ under the chest bones. The flaps were opened and all fats were removed from the organs. All stomachs, intestines and rectums were removed from the frogs and placed separately into different petri dishes. Later, the organs were opened longitudinally using a forceps and scissor. Next, $10 \mathrm{ml}$ of water was poured into the petri dishes. The contents were observed under the dissecting microscope. Helminthes were picked and kept in $70 \%$ ethanol glass bottles and labeled.

\section{Identification of helminthes}

All nematodes, trematodes and acanthocephalans were cleared in lactophenol. They were then killed in hot $70 \%$ ethanol. Nematodes were preserved in $70 \%$ glycerine alchohol, whereas trematodes and acanthocephalans were preserved in $70 \%$ ethanol. All helminthes were identified as according to the descriptions of Yamaguti [19].

\section{Environmental parameters}

pH of water: Water samples in volumes of $500 \mathrm{ml}$ were collected seven times from each sampling site and kept in different bottles. Samples were brought to the laboratory and analysis of $\mathrm{pH}$ was done within $24 \mathrm{~h}$. The values of $\mathrm{pH}$ were obtained by using a probe and meter (Hach-SensIon6 Brand).

Biochemical oxygen demand (BOD) and temperature of water: A Portable Bench-top DO meter (YSI model) was used to measure BOD of water. Seven readings were taken each for each sample and a mean obtained. Water temperature was also obtained using the same apparatus.

Rainfall distribution: The rainfall distribution data was obtained from Meteorological Department Malaysian, Ministry of Science and Environment.

\section{Wet blood smear}

A drop of fresh blood was put on a glass slide. Then the blood was mixed using the tip of a cover slide and immediately observed under compound microscope.

\section{Thin and thick blood smear}

Thin and thick blood smears were carried out. Thin blood smears were fixed in methanol and stained with Giemsa. For the thick blood smears, the slides were directly stained with Giemsa without the methanol. The slides were then examined under the compound microscope.

\section{Results}

\section{Species composition of frogs}

Fourteen species of frogs from the five families were identified: Duttaphrynus melanostictus and Phrynoidis aspera (Family Bufonidae); Fejervarya cancrivora, F. limnocharis, Limnonectes blythii, L. paramacrodon, L. ibanorum and L. ingeri (Family Digroglossidae); Microhyla butleri and Kaloula pulchra (FamilyMicrohylidae); Hylaran aerythraea, $H$. labialis and $H$. nigrovittata (FamilyRanidae); and Polypedates leucomystax (Family Rhacophoridae) (Table 1). Duttaphrynus melanostictus from Bufonidae family seemed to be the most dominant frog species in Penang Island, followed by H. erythraea from the Ranidae family. The least common species of frog was $L$. ibanorum from the Dicrossidae family.

\section{Composition of helminthes}

A total of 8058 individual helminthes were collected comprising of $43.7 \%$ nematodes, $36.8 \%$ trematodes and $19.5 \%$ acanthocephalans (Table 2). The most common nematode species were Heterakis spp., Heterakis vesicularis, Pharyngodon spp., Trichostrongylus spp., Ascaris spp., Oswaldocruzia spp. and Rhabdias spp. The three species of trematodes were Glypthelmins steffordi, Diplodiscus sacculousus and Manodistomum spp. One species of acanthocephalan was collected and identified as Macracanthorynchus spp. The frog species Duttaphrynus melanostictus seemed to be infected by almost all species of parasites

\begin{tabular}{|l|c|}
\hline Frog Species & Total number of frog caught \\
\hline Family Bufonidae & $90(27.0)^{\star}$ \\
\hline Duttaphrynus melanostictus & $47(14.1)$ \\
\hline Phrynoidis aspera & $71(21.3)$ \\
\hline Family Ranidae & $20(6.0)$ \\
\hline Hylarana erythraea & $2(0.6)$ \\
\hline Hylarana raniceps & \\
\hline Hylarana nigrovittata & $16(4.8)$ \\
\hline Family Rhacophoridae & \\
\hline Polypedates leucomystax & $10(3.0)$ \\
\hline Family Dicroglossidae & $25(7.5)$ \\
\hline Fejervarya cancrivora & $25(7.5)$ \\
\hline Fejervarya limnocharis & $3(0.9)$ \\
\hline Limnonectes blythii & $1(0.3)$ \\
\hline Limnonectes paramacrodon & $4(1.2)$ \\
\hline Limnonectes ibanorum & \\
\hline Limnonectes ingeri & $4(1.2)$ \\
\hline Family Microhylidae & $5(1.5)$ \\
\hline Microhyla butleri & $333(100)$ \\
\hline Kaloula pulchra & \\
\hline Total & \\
\hline & \\
\hline Fing in & \\
\hline
\end{tabular}

*Figure in bracket denotes percentage.

Table 1: Number of frogs caught in the eight study sites. 
Citation: Rahman WA, Shakinah Z (2015) Influence of Some Environmental Parameters on Some Frog Populations and their Parasitc Fauna. J Veterinar Sci Technol 6: 227. doi:10.4172/2157-7579.1000227

Page 3 of 5

\begin{tabular}{|c|c|c|}
\hline Species of helminthes & $\begin{array}{c}\text { Total no. of } \\
\text { Helminthes (\%) }\end{array}$ & Host Species \\
\hline Nematode & & \\
\hline Heterakis spp. & $762(9.4)$ & $\mathrm{a}, \mathrm{b}, \mathrm{c}, \mathrm{d}, \mathrm{e}, \mathrm{f}, \mathrm{g}, \mathrm{l}, \mathrm{j}, \mathrm{l}, \mathrm{n}$ \\
\hline Heterakis vesicularis & $1345(16.7)$ & $\mathrm{a}, \mathrm{b}, \mathrm{c}, \mathrm{d}, \mathrm{e}, \mathrm{f}, \mathrm{g}, \mathrm{l}, \mathrm{j}, \mathrm{l}, \mathrm{m}, \mathrm{n}$ \\
\hline Pharyngodons spp. & $1021(12.7)$ & $\mathrm{a}, \mathrm{b}, \mathrm{c}, \mathrm{d}, \mathrm{f}, \mathrm{g}, \mathrm{l}, \mathrm{j}, \mathrm{l}, \mathrm{m}, \mathrm{n}$ \\
\hline Trichostrongylus spp. & $77(1.0)$ & $\mathrm{a}, \mathrm{c}, \mathrm{f}$ \\
\hline Ascaris spp. & $272(3.3)$ & $\mathrm{a}, \mathrm{b}, \mathrm{c}, \mathrm{d}, \mathrm{f}, \mathrm{h}, \mathrm{i}$ \\
\hline Oswaldocruzia spp. & $31(0.4)$ & $\mathrm{a}, \mathrm{b}, \mathrm{c}, \mathrm{d}, \mathrm{f}, \mathrm{h}, \mathrm{j}$ \\
\hline Rhabdias spp. & $13(0.2)$ & $\mathrm{a}, \mathrm{b}, \mathrm{n}$ \\
\hline Percentage & $43.70 \%$ & \\
\hline Trematode & & \\
\hline Diplodiscus sacculousus & $144(1.8)$ & $\mathrm{a}, \mathrm{c}, \mathrm{j}$ \\
\hline Glypthelmins staffordi & $2601(32.3)$ & $\mathrm{a}, \mathrm{b}, \mathrm{c}, \mathrm{d}, \mathrm{f}, \mathrm{j}, \mathrm{,}, \mathrm{l}, \mathrm{m}$ \\
\hline Manodistomum spp. & $214(2.7)$ & $\mathrm{e}, \mathrm{f}, \mathrm{j}$ \\
\hline Percentage & $36.80 \%$ & \\
\hline Acanthocephalan & & \\
\hline Macracanthorynchus spp. & $1578(19.5)$ & $\mathrm{a}, \mathrm{b}, \mathrm{c}, \mathrm{d}, \mathrm{e}, \mathrm{f}, \mathrm{j}, \mathrm{k}, \mathrm{m}$ \\
\hline Percentage & $9.50 \%$ & \\
\hline Total number of Helminthes & $8058(100 \%)$ & \\
\hline
\end{tabular}

${ }^{*}$ Note: Denotes the respective frog species.

a: Duttaphrynus melanostictus; b:Phrynoidis aspera; c: Hylarana erythraea;

d:Polypedates leucomystax; e: Fejervarya cancrivora; f: F. limnocharis;

g: Microhyla butleri ;h:Limnonectes blythii; i: L. ibanorum; j: H. labialis;

k: L. paramacrodon; I: L.ingeri; $m$ : Kaloula pulchra, $n$ : H. nigrovittata.

Table 2: Composition of helminthes recovered from the respective frog hosts.

except for the trematode Manodistomum spp. Unlike other parasite species, four in particular were confined to three frog host species: the nematodes Trichostrongylus spp and Rhabdias spp. and the trematodes Diplodiscus sacculousus and Manodistomum spp. The acanthocephalan, Macracanthorynchus spp. seemed to be able to infect numerous species of frog hosts.

\section{Composition of blood pathogens}

As shown in Table 3, there were 105 frogs infected with blood parasites. The highest infection of blood parasite was Phrynoidis aspera $(29.5 \%)$ and the frog with the lowest blood infection was Limnonecte sibanorum (1\%) and Limnonectes kuhlii (1 \%). There were eight species of blood pathogens recovered from frogs. They comprised of Aegyptianella spp, Haemogregarina spp., Hepatozoon spp.,Lankesterella spp. Trypanosoma spp. and a microfilaria species (Table 4). Trypanosoma chattoni had the highest blood parasite count, with the lowest being seen in Lankesterellas spp.

\section{Environmental factors}

Table 5 shows four environmental factors: $\mathrm{BOD}, \mathrm{pH}$, and temperature of water and distribution of rainfall. Also, are shown the number of frogs caught and the respective helminthes, protozoa and blood pathogens obtained. From the data, the average mean of BOD was between 5.61 to $6.08 \mathrm{mg} / \mathrm{L}$. The lowest mean reading was $5.61 \mathrm{mg} / \mathrm{L}$ and the highest mean reading was $6.08 \mathrm{mg} / \mathrm{L}$. The lowest mean of $\mathrm{pH}$ was 6.16 and the highest 6.46 . The lowest reading of water temperature was $26.6^{\circ} \mathrm{C}$, while the highest $27.5^{\circ} \mathrm{C}$. Conversely, the lowest rain was $2.64 \mathrm{~mm}$ and the highest $12.99 \mathrm{~mm}$.

\section{Mean significance between frogs and parasites}

One-way ANOVA analysis and LSD test on significant mean differences between groups of helminthes parasites and frogs for $H$. vesicularis, showed there was high mean significance $(\mathrm{p}<0.05)$ in $D$.

melanostictus (63.14 \pm 24.67$), P$. aspera $(48.57 \pm 20.20)$ and $H$. erythraea $(44.00 \pm 17.06)$ compared to the other frog species: P. leucomystax, $F$. cancrivora, F. limnocharis, M. butleri, L. blythii, L. ibanorum, $H$. labialis, L. paramacrodon, L. ingeri, K. pulchra and H. nigrovittata. For Heterakis spp., there was high significance $(\mathrm{p}<0.05)$ in $P$. aspera $(33.14 \pm 27.03)$ and $H$. erythraea $(33.43 \pm 13.31)$. Ascaris spp. was the least number of parasites found in frogs. Phrynoidis aspera (29.71 \pm $8.59)$ had a high significance at level $(\mathrm{p}<0.05)$. Macracanthorynchus spp. in the frog D. melanostictus $(120.42 \pm 93.51)$ had a high mean significance $(<0.05)$ followed by Phrynoidi saspera $(34.14 \pm 18.51)$. Conversely, D. sacculousus numbers were also found to be low in frogs. But it has a high significance $(\mathrm{p}<0.05)$ in D. melanostictus $(16.42$ \pm 5.93). Glypthelmins staffordi had high significance $(\mathrm{p}<0.05)$ in $D$.

\begin{tabular}{|c|c|}
\hline Frog Species & Number Infected (\%) \\
\hline Hylarana erythraea & $23(21.9)$ \\
\hline Hylarana raniceps & $6(5.7)$ \\
\hline Hylarana nigrovittata & $2(1.9)$ \\
\hline Limnonectes ibanorum & $1(1.0)$ \\
\hline Limnonecte skuhlii & $1(1.0)$ \\
\hline Limnonectes ingeri & $4(3.8)$ \\
\hline Limnonectes paramacrodon & $2(1.9)$ \\
\hline Limnonectes blythii & $2(1.9)$ \\
\hline Fejervarya cancrivora & $2(1.9)$ \\
\hline Fejervarya limnocharis & $5(4.7)$ \\
\hline Polypedates leucomystax & $3(2.9)$ \\
\hline Phrynoidis aspera & $31(29.5)$ \\
\hline Duttaphrynus melanostictus & $23(21.9)$ \\
\hline Total (n) & $105(100)$ \\
\hline
\end{tabular}

Table 3: Species of frogs infected with blood parasites and their rates of infection.

\begin{tabular}{|c|c|}
\hline Species of blood pathogens & Total number of parasites (\%) \\
\hline Aegyptianella spp. & $387(2.0)$ \\
\hline Haemogregarina spp. & $655(3.4)$ \\
\hline Hepatozoon spp. & $2696(13.9)$ \\
\hline Lankesterella spp & $93(0.01)$ \\
\hline Trypanosom achattoni & $11770(60.6)$ \\
\hline Trypanosoma rotatorium & $3262(16.8)$ \\
\hline Trypanosoma loricatum & $131(0.7)$ \\
\hline Microfilaria & $425(2.2)$ \\
\hline Total $(\mathrm{n})$ & $19,419(100)$ \\
\hline
\end{tabular}

Table 4: Total number of blood pathogens in various species of frogs.

\begin{tabular}{|c|c|c|c|c|c|c|c|}
\hline $\begin{array}{c}\text { Sampling } \\
\text { Times }\end{array}$ & $\begin{array}{c}\text { No. of } \\
\text { Frogs/ } \\
\text { sampling }\end{array}$ & $\begin{array}{c}\text { No. of } \\
\text { helminthes/ } \\
\text { sampling }\end{array}$ & $\begin{array}{c}\text { No. of } \\
\text { protozoa } \\
\text { and blood } \\
\text { parasites/ } \\
\text { sampling }\end{array}$ & \multicolumn{3}{|c|}{ Factors (mean) } \\
\hline $\begin{array}{c}\text { Rainfall } \\
(\mathrm{mm})\end{array}$ & & & & $\begin{array}{c}\text { BOD } \\
\text { (mg/L) }\end{array}$ & $\mathrm{pH}$ & $\begin{array}{c}\text { Temp } \\
{ }^{\circ} \mathrm{C}\end{array}$ & mean \\
\hline 1 & 31 & 819 & 1232 & 5.95 & 6.46 & 27.5 & 2.64 \\
\hline 2 & 53 & 827 & 4845 & 5.63 & 6.31 & 26.8 & 6.38 \\
\hline 3 & 32 & 1518 & 3471 & 5.74 & 6.23 & 26.7 & 4.26 \\
\hline 4 & 36 & 1510 & 5315 & 5.62 & 6.16 & 26.9 & 11.97 \\
\hline 5 & 32 & 1112 & 2483 & 5.46 & 6.19 & 27.2 & 2.47 \\
\hline 6 & 50 & 1110 & 4939 & 5.61 & 6.21 & 26.6 & 12.9 \\
\hline 7 & 66 & 1162 & 3503 & 6.08 & 6.31 & 26.7 & 5.21 \\
\hline
\end{tabular}

Table 5: Number of frogs caught, number of helminthes, protozoa and blood pathogens collected per sampling, environmental factor measurements of Biochemical Oxygen Demand (BOD), $\mathrm{pH}$, temperature of water and rainfall distributions. 
melanostictus (259.85 \pm 213.66). Lankesterella spp. has significance with Duttaphrynus melanostictus $(47.14 \pm 21.21)$ at level $p<0.05,(F$ $(13,84)=3.769, p=0.000)$. Three frogs had high mean significances for Trypanosoma chattoni $(\mathrm{p}<0.05)$. They were Phrynoidis aspera (769. $28 \pm 429.55)$, Hylarana erythraea $(341 \pm 112.37)$ and D. melanostictus $(332.00 \pm 171.13)$

\section{Correlation between environmental factors and composition of parasites}

The results are presented in a matrix such that, as can be seen, the correlations were replicated (Table 6). There was a low correlation between helminthes parasites and rainfall distribution, that the Pearson correlation coefficient, $r$, was 0.321 and was statistically significant $(p<0.01)$. Also, there were negative correlations between parasites and $\mathrm{pH}(-0.713)$ at level $p<0.01$. From Table 7 , there was moderate correlation between numbers of blood parasites and levels of BOD, that the Pearson correlation coefficient, $r$, was 0.526 and statistically significant $(p<0.01)$.

\section{Discussion}

There were 300 frogs from 14 species captured in eight localities in Penang Island, Peninsular Malaysia. Different species of frogs inhabit different habitat areas. Therefore, the distribution of frogs found in every sampling site was different. There were 300 frogs from 14 species captured in eight localities in PenangIsland, Peninsular Malaysia. They were D. melanostictus, $P$. aspera, $H$. erythraea, $H$. labialis, $H$. nigrovittata, L. ingeri, L. paramacrodon, L. blythii, $L$. kuhlii, F. cancrivora, F. limnocharis, P. leucomystax, M. butleri and K. pulchra. These species had similarly been reported to occur in other parts of Malaysia as well $[4,5,9]$. The highest number of frogs collected was 90 , which was from the species D. melanostictus. This species was found in most habitats in disturbed rather than stable areas. Phrynoidisaspera was commonly found on rocks and often found in clusters rather than individuals. Oswaldocruzia spp. has not been previously recorded to occur in frog in Malaysia. A previous study discovered Oxysomatium spp. and Rhabdias spp. From D. melanostictus and F. limnocharis Batrachonema synaptospicula and Paracosmocera spp had also been described in Ranamacrodon spp.

\begin{tabular}{|c|c|c|c|c|}
\hline \multirow{4}{*}{$\begin{array}{c}\text { Correlation } \\
\text { value (r-value) }\end{array}$} & BOD & pH & $\begin{array}{c}\text { Temperature of } \\
\text { water }\end{array}$ & Rainfall \\
\cline { 2 - 5 } & -0.223 & $-0.713^{*}$ & -0.439 & $0.321^{* *}$ \\
\cline { 2 - 5 } & 1 & 0.62 & 0.315 & -0.608 \\
\cline { 2 - 5 } & 0.62 & 1 & 0.524 & -0.52 \\
\cline { 2 - 5 } & 0.315 & 0.542 & 1 & -0.573 \\
\cline { 2 - 5 } & -0.608 & -0.52 & -0.573 & 1 \\
\hline
\end{tabular}

Table 6: Result of Pearson's correlation analysis between compositions of helminthes in frogs.

\begin{tabular}{|c|c|c|c|c|}
\hline \multirow{4}{*}{$\begin{array}{c}\text { Correlation value } \\
\text { (r-value) }\end{array}$} & \multicolumn{4}{|c|}{ Environment Factor } \\
\cline { 2 - 5 } & $0.526^{*}$ & -0.076 & -0.446 & 0.143 \\
\cline { 2 - 5 } & 1 & 0.62 & 0.315 & -0.608 \\
\cline { 2 - 5 } & 0.602 & 1 & 0.524 & -0.52 \\
\cline { 2 - 5 } & 0.312 & 0.524 & 1 & -0.573 \\
\cline { 2 - 5 } & -0.608 & -0.52 & -0.573 & 1 \\
\hline
\end{tabular}

${ }^{*}$ Correlation is significant at the 0.01 levels (2-tailed)/moderate correlation.

Table 7: Result of Pearson's correlation analysis between compositions of blood pathogens in frogs. (currently L. paramacrodon) [6,8] and Paracapillaria malayensis from D. melanostictus [7]. Also, previously, frog trematodes had been recovered from Haematoloechus singaporensis from the lungs of Rana cancrivora (currently F. cancrivora), D. sacculosus from the rectums of $R$. erythraea (currently H. erythraea) and G. staffordi from the intestines of $R$. cancrivora, $R$. erythraea and $R$. macrodon. There was only one species of acanthocephalan, i.e. Macracanthorynchus spp. that was isolated. This species was abundantly found in the intestines of various species of frogs. Most of the parasites were at the larvae stage. A previous study stated that this species was found in pigs and thus the medium of infection mode is unclear. The most common adult form in amphibians is Acanthocephalu sranae [1] as well as A. bufonis [20]. However, so far, not much has been reported on Macracanthorynchus spp. and knowledge of this species is still lacking. There was no cestode recorded from this study although the study by Ibrahim et al. [9], reported a species of cestode, Nematotaenia spp. in F. cancrivo and F. limnocharis frogs in northern Peninsular Malaysia. Phrynoidis aspera and $H$. erythraea were mostly exposed to water and the chance to get infected by helminthes is higher comparing to other species. As reported by Brooks et al. [21], parasites require water for transmission when the frogs feed on aquatic intermediate hosts or when the parasite is swimming from onehost to another host. Besides that, type of habitat also contributes to the parasite infection. A previous study by Kusrini et al. [22] reported that the higher prevalence in nematode infection is mostly in terrestrial frogs compared to dwelling frogs. Since $D$. melanostictus is a terrestrial frog, thus explaining that D. melanostictus was infected with $H$. vesicularis.

With regards to blood pathogens, 105 of 300 frogs were infected with at least one species of Lankesterella spp. and T. chattoni. There were significant differences in the means of parasitism among frog species, with blood parasite detected in only 2 of 8 species. Trypanosoma chattoni was the most common blood parasite. Other studies had also reported that Trypanosoma spp. Lankesterella were the most common parasite observed in frogs [23]. This study found that significant differences in the means of blood parasite among frog species, possibly reflecting the different habitat preferences of the host species and consequently different vector abundance and interaction rates. Environmental factors did not influence the infection rate of parasitism in frogs except for rainfall. According to Brooks et al. [21], parasites require water for transmission, either when the frog utilizes aquatic intermediate hosts like trematodes, or when the parasite is swimming from one host to another like in mono geneans, thus explaining the high number of parasites during the rainy season [2427]. There was no relationship between $\mathrm{pH}$ and parasite numbers since $\mathrm{pH}$ values remained unchanged throughout the sampling period. BOD and temperature did not influence the number of parasites although the reason for this is not clear.

\section{References}

1. Duellman WE, Trueb L (1986) Biology of Amphibians. United States. McGrawHill Publication, pp. 670.

2. Hayes MP, Jennings MR (1986) Decline of Ranid frog species in Western North America: are bullfrogs responsible? Journal of Herpetology 20: 490-509.

3. Department of Meteorology Malaysia (2011) Ministry of Science, Technology and Inovation, Malaysia.

4. Inger RF, Stuebing RB (2005) A Field Guide to The Frogs of Borneo. Borneo Sarawak. Natural History Publication. pp. 209.

5. Ibrahim J, Shahrul AMS, Norhayati A, Chan KO, Muin MA (2008) The Common Amphibians and Reptiles of Penang Island, Peninsular Malaysia. State Forestry Department of Penang, Malaysia. pp 116. 
Citation: Rahman WA, Shakinah Z (2015) Influence of Some Environmental Parameters on Some Frog Populations and their Parasitc Fauna. J Veterinar Sci Technol 6: 227. doi:10.4172/2157-7579.1000227

6. Fusco AC, Palmieri JR (1979) The nematode fauna of Rana macrodon Dumeril and Bibron with supplementary data on Batrachonema Synaptospicula Yuen, 1965 (Nematoda: Amidostomatidae). Proc Helminthological Soc Washington, 46: $289-292$.

7. Moravec F, ModrA D, JirkA M (2007) A new species of Paracapillaria (Nematoda: Capillariidae) from the intestine of the toad Duttaphrynus melanostictus (Anura) from the Malayan Peninsula. J Parasitol 93: 907-909.

8. YUEN PH (1962) Three trematodes from Malayan amphibians including two new species. J Parasitol 48: 532-535.

9. Ibrahim J, Samsudin R, Akil MM (1997) Parasite fauna of Rana cancrivora Gravenhorst and R. limnocharis Boie from District IV of The Muda Agricultural Development Authority (MADA) Scheme, Kedah. Proceedings of Universit Sains Malaysia, pp 119-29.

10. Yong Alford RA, Richards SJ (1999) Global amphibian declines: a problem in applied ecology. Annual Review of Ecology and Systematics 30:133-165.

11. Daszak $P$, Cunningham AA, Hyatt AD (2000) Emerging infectious diseases of wildlife--threats to biodiversity and human health. Science 287: 443-449.

12. Houlahan JE, Findlay CS, Schmidt BR, Meyer AH, Kuzmin SL (2000) Quantitative evidence for global amphibian population declines. Nature 404 : 752-755.

13. Pounds JA, Fogden MPL, Campbell JH (1999) Biological response to climate change on a tropical mountain. Nature 398: 611-615.

14. Carey C (2000) Infectious disease and worldwide declines of amphibian populations, with comments on emerging diseases in coral reef organisms and in humans. Environ Health Perspect 108 Suppl 1: 143-150.

15. Carey C, Cohen N, Rollins-Smith L (1999) Amphibian declines: an immunological perspective. Dev Comp Immunol 23: 459-472.

16. Maniero GD, Carey C (1997) Changes in selected aspects of immune function in the leopard frog, Rana pipiens, associated with exposure to cold. J Comp Physiol B 167: 256-263.
17. Macinnis AJ (1976) How parasites find hosts. Some thoughts on the inception of host-parasite integration. In: Ecological Aspects of Parasitology. Edited by Kennedy, C.R. North-Holland Publishing Co. Amsterdam. 3-20 pp.

18. Lafferty KD, Kuris AM (1999) How environmental stress affects the impact of parasites. Limnology and Oceanography 44: 925-931.

19. Yamaguti S (1961) Systema Helminthum. Vol III. The Nematodes of Vertebrates. Interscience Publishers Inc. New York, p. 1261.

20. Goldberg SR, Bursey CR, Kraus F (2007) First report of gastrointestinal helminthes from the Cannibal Frog, Lechriodus melanopyga (Amphibia: Limnodynastidae), from Papua New Guinea. Pacific Science 61: 429-432.

21. Brooks DR, León-Règagnon V, McLennan DA, Zelmer D (2006) Ecological fitting as a determinant of the community structure of platyhelminth parasites of anurans. Ecology 87: S76-85.

22. Kusrini MD, Suzanna E, Satrija F (2003) Endoparasites of two species of edible frogs, Limnonectes macrodon, Boie and Fejervarya cancrivora,

23. Desser SS (2001) The blood parasites of anurans from Costa Rica with reflections on the taxonomy of their trypanosomes. J Parasitol 87: 152-160.

24. Kiesecker JM, Blaustein AR (1995) Synergism between UV-B radiation and a pathogen magnifies amphibian embryo mortality in nature. Proc Natl Acad Sci U S A 92: 11049-11052.

25. Gravenhorst, from Bogor, Indonesia. Prosiding Seminar Hasil Penilitian Departmen Konservasi Sumberdaya Hutan, 53-64.

26. Wahab AR, Andy Tan WA, Intan S (2008) On the parasitic fauna of two species of anurans collected from Sungai Pinang, Penang Island, Malaysia. Trop Biomed 25: 160-165.

27. Tyler MJ, Wassersug R, Smith B (2007) How frogs and human interact: Influences beyond habitat destruction, epidemics and global warming. Applied Herpetology 4: 1-18. 